http://jmscr.igmpublication.org/home/ ISSN (e)-2347-176x ISSN (p) 2455-0450

crossref DOI: https://dx.doi.org/10.18535/jmscr/v7i9.84

$\underline{\text { Research Article }}$

\title{
A Quasi Experimental Study to Assess the Effectiveness of Structured Teaching Program on Epilepsy and Its Management among Students in Selected Educational Colleges, Punjab
}

\author{
Author \\ Manvirpal Kaur \\ Guru Hargobind College of Nursing, Raikot, Ludhiana, Punjab (India)
}

\begin{abstract}
The present study was conducted to assess the effectiveness of structured teaching program on epilepsy and its management among students in selected educational colleges, Punjab. The main purpose of the study was to create awareness among students of educational colleges regarding epilepsy and its management through structured teaching program. The Conceptual framework was developed on the basis of General System Theory by Ludwig Von Bertalanffy $(1968)^{27}$. A self structured multiple choice questionnaire on epilepsy and its management was prepared to assess the knowledge of students. An experimental research approach and quasi experimental research design was adopted 60 students were selected by using non probability convinient sampling technique. The independent variables in the study were age(in years), gender, type of family, family income per month, religion, area of residence, family history of epilepsy, source of information. The dependent variable in the study was knowledge of students of educational colleges regarding epilepsy and its management. A self structured knowledge questionnaire on epilepsy and its management was prepared. The data was analysed by descriptive and inferential statistics. Following results were drawn based on findings of study. It showed that in experimental and control group respectively, majority $(50 \%, 63.33 \%)$ of students were from age group 22-25 years and highest (53.33\%,70\%)were females, maximum $(56.67 \%, 56.67 \%)$ from nuclear and joint families, majority $(63.33 \%, 36.67 \%)$ had family income per month $\geq 15,001$ and 5,001-10,000. Maximum $(56.67 \%, 73.33 \%)$ were from Sikh religion and maximum $(93.33 \%, 100 \%)$ students had not family history of epilepsy in experimental and control group respectively. Most $(60 \%, 73.33 \%)$ of students were from urban and rural area and majority $(36.67 \%, 70 \%)$ of students gained information from other source of information and TV/Radio. The difference between mean pre test knowledge scores on epilepsy and its management among students in experimental and control group was non significant but difference between post test knowledge score was significant statistically. There was statistically significant effect of age, family income per month, religion, source of information on student's knowledge regarding epilepsy and its management. There was statistically non-significant effect of gender, type of family, area of residence, family history on student's knowledge regarding epilepsy and its management.
\end{abstract}

\section{Major Findings}

1. Both in experimental and control group maximum $(50 \%, 63.33 \%)$ students were in age group of 22-25 years. In experimental and control group majority $(53.33 \%, 70 \%)$ students were females. In experimental 
group maximum $(56.67 \%)$ students were from nuclear family. In the control group majority $(56.67 \%)$ students were from joint family. In experimental group maximum $(63.33 \%)$ students had family income $\geq 15,001$.In the control group majority $(36.67 \%)$ students had family income 5,001-10,000 and 10,001-15,000. In experimental and control group maximum $(56.67 \%, 73.33 \%)$ students belonged to Sikh religion. In experimental group majority (60\%) students were belonged to urban area. In the control group majority $(73.33 \%)$ students were belonged to rural area. In experimental and control group $(93.33 \%, 100 \%)$ students had not family history of epilepsy. In experimental group maximum (36.67\%) students were exposed to other source of information. In the control group maximum 21(70\%) students exposed to TV/Radio.

2. The pre test mean knowledge score of experimental group was19.53, whereas in control group the pre test mean knowledge score was 18.33 . Hence, it was concluded that the pre test mean knowledge score of both the experimental and control group was average. The post test mean knowledge score of experimental group the was 31.10 whereas in control group the post test mean knowledge score was 20.00. Hence, it was concluded that the post test mean knowledge score of the experimental group was higher than post test mean knowledge score of control group.

3. 3. The difference between pre test mean knowledge scores of experimental and control group $(19.53,18.33)$ was observed non significant by ANOVA whereas the difference between post test mean knowledge score among experimental and control group $(31.10,20.00)$ was observed significant at $\mathrm{p}<0.05$ level.
4. In Pre test of experimental and control group the majority of students $(80.00 \%$, $56.67 \%$ ) had average knowledge score respectively. In Post test of experimental group the majority of students $(80.00 \%)$ had good knowledge score and in post test of control group, the majority $(73.33 \%)$ students had average knowledge score.

5. The pre test and post test mean knowledge score of experimental group was (19.53, 31.10) respectively. The difference between the pre test and post test knowledge score of experimental group was statistically significant at the level of $\mathrm{p}<0.05$. The pre test and post test mean knowledge score of control group was $(18.33,20.00)$ respectively. The difference between the pre test and post test knowledge score of control group was non significant by ANOVA.

6. In experimental group, the maximum pre test mean knowledge score (19.93) was obtained by the students who were in age group of 22-25 years and post test maximum (31.86) mean knowledge score was obtained by students who were in age group22-25 years. In control group, the maximum (19.4) pre test mean knowledge score was obtained by students who were in age group 26-29 years and in post test maximum (20.21) mean knowledge score was obtained by students who were in age group 22-25 years.

7. In experimental group, the maximum pre test and post test mean knowledge score among students $(20.31,31.81)$, was obtained by females. In control group, the maximum $(20.14,20.40)$ pre test and post test mean knowledge score was obtained by students was females.

8. In experimental group, the maximum pre test and post test mean knowledge score (19.94, 31.82) among students, was obtained by those who belonged to nuclear families. In control group, the maximum 
$(20.08,20.15)$ pre test and post test mean knowledge score was obtained by students who belonged to nuclear families.

9. In experimental group, highest (20.33) pre test mean knowledge score was obtained among students whose family income per month was 15,001-10,000 and in post test maximum (32.28) mean knowledge score was obtained among students who had family income per month was 10,00115,000.In control group, maximum $(22,21)$ pre test and post test mean knowledge score was obtained among students whose family income per month was $\leq 5,000$.

10. In experimental group, maximum (20.44, 31.67) pre test and post test mean knowledge score was obtained among students who belonged to Hindu religion. In control group, maximum $(24,24.50)$ pre test and post test mean knowledge score was obtained among students who belonged to Muslim religion.

11. In experimental group, the maximum pre test mean knowledge score(20.39) was obtained by students who belonged to urban area of residence and in post test maximum(31.83) mean knowledge score was obtained by students who belonged to rural area of residence. In control group, the maximum $(19.14,20.09)$ pre test and post test mean knowledge score was obtained by students who belonged to rural area of residence.

12. In experimental group, the maximum pre test mean knowledge score (21.50) obtained by students who had family history of epilepsy and in post test maximum (31.10) mean knowledge score was obtained by students who had not family history of epilepsy. In control group, the maximum $(18.33,20)$ pre test and post test mean knowledge score was obtained by students who had not family history of epilepsy.

13. In experimental group, the maximum (20.67) pre test mean knowledge score was obtained by students who exposed to Internet and in post test maximum (32.64) mean knowledge score was obtained by students who were exposed to other source of information. In control group, the maximum $(28,22)$ pre test and post test mean knowledge score was obtained among students who exposed to other source of information.

\section{Section-II}

\section{Objective1}

To assess the pretest knowledge score regarding epilepsy and its management among students of educational colleges in control and experimental group.

Table 2 Pre test Mean Knowledge Score regarding Epilepsy and its Management among Students of Educational Colleges in Experimental and Control Group.

$\mathrm{N}=60$

\section{Knowledge Score}

\begin{tabular}{|l|c|c|}
\hline \multirow{3}{*}{ Group } & \multirow{2}{*}{$\mathbf{n}$} & Pre test \\
\cline { 3 - 3 } & & Mean \\
Experimental & 30 & 19.53 \\
& & 3.11 \\
\hline Control & 30 & 18.33 \\
& & 4.78 \\
\hline
\end{tabular}

Minimum Score $=0$

Table 2 and figure 3 revealed that pre test mean knowledge score of experimental group was (19.53), whereas the pre test mean knowledge score of control group was (18.33).

Hence, it was concluded that the pre test mean knowledge score of both the experimental and control group was average. 


\section{JMSCR Vol||07||Issue||09||Page 490-495||September}

Table 3 Frequency and Percentage Distribution of Pre test Knowledge Score regarding Epilepsy and its Management among Students of Educational colleges in Experimental and Control Group

\begin{tabular}{|c|c|c|c|c|c|c|}
\hline & & & & & & \\
\hline \multirow{4}{*}{$\begin{array}{l}\text { Level of } \\
\text { Knowledge }\end{array}$} & \multirow{4}{*}{$(\%)$} & \multirow{4}{*}{ Score } & \multicolumn{4}{|c|}{ Knowledge score } \\
\hline & & & \multirow{2}{*}{\multicolumn{2}{|c|}{$\begin{array}{l}\begin{array}{l}\text { Experimental } \\
\text { Group }(\mathbf{n}=30)\end{array} \\
\text { Pre-test }\end{array}$}} & \multirow{2}{*}{\multicolumn{2}{|c|}{$\begin{array}{l}\begin{array}{l}\text { Control Group } \\
(\mathbf{n}=\mathbf{3 0})\end{array} \\
\text { Pre-test }\end{array}$}} \\
\hline & & & & & & \\
\hline & & & $\mathbf{n}$ & $\%$ & $\mathbf{n}$ & $\%$ \\
\hline Excellent & $(\geq 81)$ & $\geq 33$ & 0 & 0 & 0 & 0 \\
\hline Good & $(61-80)$ & $25-32$ & 1 & 03.33 & 4 & 13.33 \\
\hline Average & $(41-60)$ & $17-24$ & 24 & 80.00 & 17 & 56.67 \\
\hline Below average & $(\leq 40)$ & $\leq 16$ & 5 & 16.67 & 9 & 30.00 \\
\hline
\end{tabular}

Maximum score $=40$

Minimum score $=0$

Table 3 and figure 4 revealed that frequency and percentage distribution among students according to Pre test knowledge score regarding epilepsy and its management. In experimental group the majority of students $24(80.00 \%)$ had average knowledge score, followed by $5(16.67 \%)$ below average and remaining $1(3.33 \%)$ had good knowledge score.
In control group Pre test knowledge score maximum 17(56.67\%) students had average knowledge score, followed by $9(30.00 \%)$ below average and remaining $4(3.33 \%)$ had good knowledge score. None of students in both experimental and control group had excellent knowledge. Thus, it was concluded that in both experimental and control group, the students had average knowledge score in their Pre test.

Table - 14 Relationship of Pre-test and Post test Mean Knowledge score regarding Epilepsy and its Management among Students of Educational Colleges in Experimental and Control Group according to Source of Information.

\begin{tabular}{|c|c|c|c|c|c|c|c|c|c|c|}
\hline & & & & & & & & & \multicolumn{2}{|c|}{$\mathrm{N}=60$} \\
\hline \multirow[t]{4}{*}{ Source of Information } & \multirow[t]{4}{*}{$\mathbf{n}$} & \multicolumn{9}{|c|}{ Knowledge Score } \\
\hline & & \multicolumn{4}{|c|}{ Experimental Group $(\mathbf{n}=30)$} & & \multicolumn{4}{|c|}{ Control Group $(\mathrm{n}=30)$} \\
\hline & & \multicolumn{2}{|c|}{ Pre-test } & \multicolumn{2}{|c|}{ Post test } & & \multicolumn{2}{|c|}{ Pre-test } & \multicolumn{2}{|c|}{ Post test } \\
\hline & & Mean & SD & Mean & SD & $\mathbf{n}$ & Mean & SD & Mean & SD \\
\hline TV/Radio & 7 & 18.14 & 2.17 & 30.14 & 2.64 & 21 & 17.14 & 4.39 & 19.48 & 3.30 \\
\hline Internet & 6 & 20.67 & 5.02 & 30.05 & 4.68 & 4 & 21.50 & 3.77 & 21 & 3 \\
\hline Newspaper/ Magazine & 6 & 20 & 2.24 & 30 & 1.15 & 4 & 22 & 1 & 21.25 & 1.30 \\
\hline \multirow[t]{2}{*}{ Others } & 11 & 19.54 & 2.19 & 32.64 & 2.23 & 1 & 28 & 0 & 22 & 0 \\
\hline & & df & $\mathbf{F}$ & df & $\mathbf{F}$ & & df & $\mathbf{F}$ & df & $\mathbf{F}$ \\
\hline \multicolumn{2}{|l|}{ Between group } & 3 & $5.26^{*}$ & 3 & $6.31 *$ & & 3 & $4.21 *$ & 3 & $1.97^{\mathrm{NS}}$ \\
\hline \multicolumn{2}{|l|}{ Within group } & 26 & & 26 & & & 26 & & 26 & \\
\hline \multicolumn{3}{|l|}{ Maximum Score $=40$} & & & \multicolumn{6}{|c|}{ NS=Non Significant at $p<0.05$} \\
\hline \multicolumn{3}{|l|}{ Minimum Score $=0$} & & & & & \multicolumn{4}{|c|}{$*$ Significant at $\mathrm{p}<0.05$} \\
\hline
\end{tabular}

Table 14 and Figure 15 depicts that in experimental group, the maximum 20.67 pre test mean knowledge score was obtained by students who exposed to Internet, followed by 20 to Newspaper/ Magazine, then 19.54 to other source of information and least 18.14 to TV/Radio and in post test maximum 32.64 mean knowledge score was obtained by students who exposed to other source of information, followed by 30.14 to
TV/Radio, then 30.5 to Internet and least 30 to Newspaper/magazine. The relationship of the pre test mean knowledge score was found statistically $\mathrm{h}$ significant at $\mathrm{p}<0.05$ level and the relationship of post test mean knowledge score was also found statistically significant at $\mathrm{p}<0.05$ level.

In control group, maximum 28 pre test mean knowledge score was obtained among students who exposed to other source of information, 
followed by 22 to Newspaper/magazine then 21.5 to Internet and least 17.14 to TV/Radio and in post test maximum 22 mean knowledge score was obtained among students who exposed to other source of information, followed by 21.25 to Newspaper/Magazine, then 21 to Internet and least 19.48 to TV/Radio. . The relationship of the pre test mean knowledge score was found statistically significant at $\mathrm{p}<0.05$ level and the relationship of post test mean knowledge score was found statistically non significant by ANOVA. Hence, it was inferred that source of information had a definite impact on knowledge regarding epilepsy and its management among students. A structured teaching program had also a great influence on knowledge of students regarding epilepsy and its management.

\section{References}

1. Park J.E. Preventive and social medicine. 18th Edition. Jabalpur: Banarsidas Bhanot Publishers, 2005.

2. Black Joyce M., Jane Hokanson Hawks. Medical Surgical Nursing-clinical management for positive outcomes. $7^{\text {th }}$ Edition. Elsevier publishers, 2004; 2: 2073-2074.

3. WHO, Epilepsy Facts, WWW.Who.int/mental_health/neurology/ epilepsy/en, 2007.

4. Krishnakumar Asha. Epidemiology. India's National Magazine. Hindu Publishers: 2000, 17(21).

5. 5.National Institute of Neurological Disorders and Stroke, Seizures and epilepsy:

Hopethroughresearch,http://www.ninds.ni h.gov/disorders/epilepsy/detail_epilepsy.ht m,2010 May.

6. Raymond AA, Fish DR, Sisodiya SM et al. Abnormalities of gyration, heterotopias, tuberous sclerosis, focal cortical dysplasia, microdysgenesis, dysembryoplastic neuroepithelial tumors and digenesis of the archicortex in epilepsy. Brain. 1995; 118:629-660.

7. Ghai C.L, Text book of Human Neurophysiology; $1^{\text {st }}$ edition: 259-260.

8. Hauser WA, Annegers JF, Kurland LT. Incidence of epilepsy and unprovoked seizures in Rochester, Minnesota: Journal of Epilepsia. 1993; 34: 453-68.

9. WHO, Epilepsy: Historical overview and social consequences and economic aspects. 2007,WWW.Who.int/mediacentre/factshee ts/fs165/en.

10. Priyadarshini Sangeetha .Introduction of epilepsy. The Nursing Journal of India. December $2010 ; 12$.

11. Sirven JI, Lopez RA, Vazquez B, Van Haverbeke P. Attitudes and knowledge of epilepsy by Spanish-speaking adults in the United States.Journal of Epilepsy Behaviour. 2005; 7:259--65.

12. Lee, S.A., Yoo, H.J., \& Lee. Factors Contributing to the Stigma of Epilepsy. Journal on Seizure; 2005; 14:157-163.

13. Baker GA, Camfield C, Camfield P, Cramer JA, Elger CE, Johnson AL, et al. Commission on outcome measurement in epilepsy. final report.Journal of Epilepsia 1998; 39: 213-31.

14. Hesdorffer DC, Hauser WA . Epilepsy: Frequency, Causes and Consequences. NewYork;DemosPublications;1990:297326,http://www.efa.org/epusa/nation.html\# 10.

15. Craig AG, Oxley J, Dowds C. Children and Young People with Epilepsy: an Educational Package for Teachers. Chalfont St Peter: National Society for Epilepsy. 2010.

16. Rao Gayathri .The knowledge, attitudes, and practices with respect to epilepsy among health science students of Manipal University. Journal of Epilepsy and Behavior, 2011:20 (3): 447-449.

17. Guptha N. Epilepsy freedom from stigma. Journal onEpilepsy.2007:1-34. 
18. West MD, Dye AN, McMahon BT: Epilepsy and workplace discrimination: population characteristics and trends. Journal of Epilepsy and Behavior, 2006; 9:101-5.

19. Fatah Ab, Rahman Ab. Journal of Epilepsy and behavior. 2005:14(8):593-596.

20. Pandian JD, et al. High school students' knowledge, attitude, and practice with respect to epilepsy in Kerala, southern India. Acta Neurol Scand. Jul 2004; 110(1):39-45. 